Ambiente \& Água - An Interdisciplinary Journal of Applied Science
ISSN 1980-993X - doi:10.4136/1980-993X
www.ambi-agua.net
E-mail: ambi.agua@gmail.com

\title{
Physical-chemical effects of irrigation with treated wastewater on Dusky Red Latosol soil
}

\author{
doi:10.4136/ambi-agua.1695
}

Received: 02 Jul. 2015; Accepted: 01 Oct. 2015

\author{
Vanessa Ribeiro Urbano ${ }^{1}$; Thaís Grandizoli Mendonça ${ }^{1 *}$; \\ Reinaldo Gaspar Bastos ${ }^{2}$; Claudinei Fonseca Souza ${ }^{1}$ \\ ${ }^{1}$ Universidade Federal de São Carlos (UFSCar), Araras, SP, Brasil \\ Departamento de Recursos Naturais e Proteção Ambiental (DRNPA) \\ ${ }^{2}$ Universidade Federal de São Carlos (UFSCar), Araras, SP, Brasil \\ Departamento de Tecnologia Agroindustrial e Sócio economia Rural (DTAiSER) \\ "Corresponding author: e-mail: thais_gmendonca@ yahoo.com.br, \\ nessaru@gmail.com, reinaldo@cca.ufscar.br, cfsouza@cca.ufscar.br
}

\begin{abstract}
The current water crisis underlines the importance of improving water management. The use of effluent from secondary treatment in agriculture can reduce the discharge of effluent into natural bodies and provide nutrients to crops. This study evaluated the physical and chemical properties of a Dusky Red Latosol soil that had been irrigated with treated wastewater. Conducted at the Center of Agricultural Sciences (CCA) of Federal University of São Carlos (UFSCar), in Araras/São Paulo/Brazil, 18 undisturbed soil samples were collected and deposited on a constant-head permeameter in order to simulate the irrigation of five growth cycles of lettuce (Lactuca sativa L.), organized in five different treatments and one control group. For each treatment $0.58 \mathrm{~L}, 1.16 \mathrm{~L}, 1.74 \mathrm{~L}, 2.32 \mathrm{~L}$, and $2.90 \mathrm{~L}$ of treated wastewater and distilled water were applied. The treated wastewater came from a domestic waste treatment plant. After the water filtered through the soil, samples of treated wastewater were collected for analyses of electrical conductivity (EC), sodium adsorption ratio (SAR), turbidity, $\mathrm{pH}, \mathrm{Na}, \mathrm{K}, \mathrm{Mg}, \mathrm{P}$ and $\mathrm{Ca}$ and, in the soil the granulometry, complete fertility, exchangeable sodium percentage (ESP) and saturated hydraulic conductivity (Ksat). The Ksat decreased, but did not alter the infiltration of water and nutrients in the soil. The concentration of nutrients in the soil increased, including $\mathrm{Na}$, which raises the need for monitoring soil's salinity. In conclusion, the application of wastewater did not cause damage to the physical properties of the soil, but resulted in a tendency towards salinization.
\end{abstract}

Keywords: agriculture, effluent, salinity, water reuse.

\section{Efeitos físico-químicos da irrigação com água de reúso em um Latossolo Vermelho distrófico}

\section{RESUMO}

A atual crise da água ressalta a importância de se melhorar a gestão da água. O uso de efluente de tratamento secundário na agricultura pode reduzir a descarga de efluentes em corpos naturais e fornecer nutrientes para as culturas. Este estudo teve como objetivo avaliar 
as propriedades físicas e químicas de um Latossolo Vermelho distrófico irrigado com água de reúso. Conduzido no Centro de Ciências Agrárias (CCA) da Universidade Federal de São Carlos (UFSCar), em Araras/SP/Brasil, 18 amostras indeformadas de solo foram coletadas e dispostas em permeâmetro de carga constante para simular a irrigação de 5 ciclos de cultivo de alface (Lactuca sativa L.), organizado em cinco diferentes tratamentos e um grupo controle. Para cada tratamento foram aplicados 0,58 L, 1,16 L, 1,74 L, 2,32 L, e 2,90 L de água de reúso e água destilada. A água de reúso usada nesse estudo provém de uma planta de tratamento de esgoto doméstico. Após a passagem da água pelo solo, amostras da água de reúso tratada e água destilada foram coletadas e analisada a condutividade elétrica (CE), razão de adsorção de sódio (RAS), turbidez, $\mathrm{pH}, \mathrm{Na}, \mathrm{K}, \mathrm{Mg}, \mathrm{P}$ e $\mathrm{Ca}$, e no solo a granulometria, a fertilidade completa, porcentagem de sódio trocável (PST) e condutividade hidráulica (Ksat). A Ksat diminuiu, mas isto não prejudicou a infiltração de água e nutrientes no solo. A concentração de nutrientes no solo aumentou, incluindo o $\mathrm{Na}$, o que requer monitoramento da salinidade do solo. Conclui-se que a aplicação da água de reúso não causou danos às propriedades físicas do solo, mas resultou em tendência à salinização.

Palavras-chave: agricultura, efluente, reúso de água, salinidade.

\section{INTRODUCTION}

There is a concern for developing strategies and effective improvements in order to solve the water scarcity problems that are already a reality in some regions. The reuse of treated wastewater has increased in agriculture, with the objective of saving scarce water resources as well as maintaining environmental quality by reducing effluent discharge into water bodies (Plevich et al., 2012; Singh et al., 2012).

In order to reassess the management of water used for these activities, many countries, such as Brazil, Italy, India, Spain and United States are investing in research that promotes irrigation using treated wastewater (Javarez Jr. et al., 2010; Pereira et al., 2011; Cirelli et al., 2012; Pedrero et al., 2012; Singh et al., 2012; Souza et al., 2015) due to its potential economic and environmental benefits (Cirelli et al., 2012). In other words, reclaimed wastewater has the potential to provide nutrients available in ionic forms and to promote a small but steady supply of nutrients to plants as slow-release fertilizers (Pereira et al., 2011).

Despite the beneficial aspects of reuse, the application of treated wastewater to soil raises concerns about physical-chemical soil parameters that can drastically affect soil quality and crop development. Undesirable substances such as salts in high concentrations, dissolved solids, toxic agents, microorganisms and heavy metals may be present in the water (Sampaio et al., 2010; Nathan et al., 2012; Singh et al., 2012; Varallo et al., 2012).

Soil fertility is evaluated by measuring chemical properties such as $\mathrm{pH}$, organic matter, phosphorus, potassium, calcium, magnesium, aluminum + hydrogen, cation exchange capacity, base saturation and others (Reichardt and Timm, 2004), so it is important to note that the presence of these nutrients in treated wastewater is a problem only when their concentrations are too high once the treated wastewater can be used as a fertilizer supply (Baumgartner et al., 2007; Dantas et al., 2014; Cuba et al., 2015; Gabrielli et al., 2015).

The quality of water applied to soil does not depend only upon the total amount of salts, but also upon the salt type. Some types of saline water could damage the soil when used for a long time. The most common soil problems associated with water salinity are the velocity of water infiltration through soil and toxicity to plants (Ayers and Westcot, 1999).

When salt concentration in the soil is high, the movement of the water from the soil to the plant roots decreases and when salt concentration is higher in soil than in roots the 
movement is the opposite and can cause a loss of water in plants (Meurer, 2010). The main damages that saline water can cause to soil are described by several authors: decrease of soil permeability, clay and organic matter dispersion and decrease of soil infiltration rate, which can prevent root development (Mantovani et al., 2009; Meurer, 2010; Varallo et al., 2012).

The main ions in soil affected by salts are the cations $\mathrm{Na}^{+}, \mathrm{Ca}^{2+}, \mathrm{Mg}^{2+}, \mathrm{K}^{+}$, and the anions $\mathrm{Cl}^{-}, \mathrm{SO}_{4}{ }^{2-}, \mathrm{HCO}_{3}{ }^{-}, \mathrm{CO}_{3}{ }^{2-}$ and $\mathrm{NO}_{3}^{-}$, forming chlorides, sulfates, nitrates, carbonates and bicarbonates which are quite soluble (Meurer, 2010). Electrical conductivity is used to evaluate the potential of irrigation water to promote soil salinity, which represents the total amount of salts in the water, with no speciation (Almeida, 2010). Specifically, the amount of sodium in irrigation water can be determined by evaluating the sodium adsorption rate (SAR).

Saturated hydraulic conductivity of soil (Ksat) characterizes the porous permeability of soil and can be classified as permeable, semi permeable and low permeable (Mantovani et al., 2009). This parameter is therefore important, because it relates to water infiltration through soil and the consequent availability of nutrients to roots (Bonini et al., 2011).

Effects of treated wastewater application on the chemical properties of soil are noticeable only after long period of application, and can vary depending on physical-chemical soil composition, climate conditions and soil type (Costa et al., 2014). In this context, this study evaluated the physical and chemical properties of Dusky Red Latosol soil that had been irrigated with treated wastewater simulating the irrigation volume corresponding to five cycles of lettuce cultivation.

\section{MATERIAL AND METHODS}

The irrigation volume of five growth cycles of lettuce were simulated in a constant-head hydraulic permeameter installed at the Laboratory of Soil Pollution at the Center of Agricultural Sciences (CCA) of the Federal University of São Carlos (UFSCar), located in the city of Araras in the Brazilian state of São Paulo. The experiment was conducted in November and December of 2011 and consisted of two treatments, treated wastewater and distilled water (control). Each treatment was divided in 5 blocks corresponding to lettuce cycles with 3 repetitions. The use of lettuce is justified because it is a much-studied crop in water reuse (Sandri et al., 2006; Sandri et al., 2007; Baumgartner et al., 2007; Varallo et al., 2012).

The treated wastewater came from a sewage treatment plant located at the University of Campinas (Unicamp), School of Agricultural Engineering (FEAGRI). The sewage treatment system used by Unicamp consists of a sandbox, followed by an anaerobic baffled reactor and at the end by wetlands. After the treatment, the characteristics of the treated wastewater were analyzed, including calcium $(\mathrm{Ca})$, phosphorus $(\mathrm{P})$, magnesium $(\mathrm{Mg})$, potassium $(\mathrm{K})$, sodium (Na), nitrate $\left(\mathrm{NO}_{3}{ }^{-}\right), \mathrm{pH}$, turbidity, sodium adsorption ratio (SAR) and electrical conductivity (EC) (Table 1). Distilled water was used in the control group.

Table 1. Chemical-physical characteristics of treated wastewater used in the experiment.

\begin{tabular}{cccccccccc}
\hline $\mathrm{Ca}$ & $\mathrm{P}$ & $\mathrm{Mg}$ & $\begin{array}{c}\mathrm{K} \\
\left(\mathrm{mg} \mathrm{L}^{-1}\right)\end{array}$ & $\mathrm{Na}$ & $\mathrm{NO}_{3}^{-}$ & $\mathrm{pH}$ & $\begin{array}{c}\text { Turbidity } \\
(\mathrm{UNT})\end{array}$ & $\begin{array}{c}\mathrm{SAR} \\
\left(\mathrm{mmol}_{\mathrm{c}} \mathrm{L}^{-1}\right)^{1 / 2}\end{array}$ & $\begin{array}{c}\mathrm{EC} \\
\left(\mathrm{dS} \mathrm{m}^{-1}\right)\end{array}$ \\
\hline 15.67 & 10.84 & 0.17 & 26.4 & 53.7 & 47.0 & 6.86 & 0.61 & 3.9 & 0.8 \\
\hline
\end{tabular}

The average amount of water necessary to cultivate one cycle of lettuce (Lactuca sativa L.) is $150 \mathrm{~mm}$ (Varallo et al., 2010; Sandri et al., 2007). This amount was scaled for the total area of the metallic cylinders $\left(38.465 \mathrm{~cm}^{2}\right)$, resulting in the following amounts from the first to the fifth simulated cycle: $0.58 ; 1.16 ; 1.74 ; 2.32$ and $2.90 \mathrm{~L}$, 
respectively. The control treatment consisted of $2.90 \mathrm{~L}$ of distilled water.

At a depth of 0-20 cm, 18 undisturbed samples of Dusky Red Latosol soil type were collected in a greenhouse at the experimental area of the CCA $\left(22^{\circ} 18\right.$ ' 53" South and $47^{\circ} 23^{\prime} 00^{\prime}$ "West). The soil came from an area that had only conventional cultivation and was never irrigated with wastewater.

The bases of the cylinders were sealed with a double layer of a permeable, multipurpose cloth to avoid soil loss. A cylinder of the same model and size was coupled to the top of each sample cylinder to allow the stabilization of a constant water level.

The experiment was performed in a constant-head permeameter. The water quantity and also water supply rate were controlled at a constant flow with a Mariotte bottle (Figure 1).

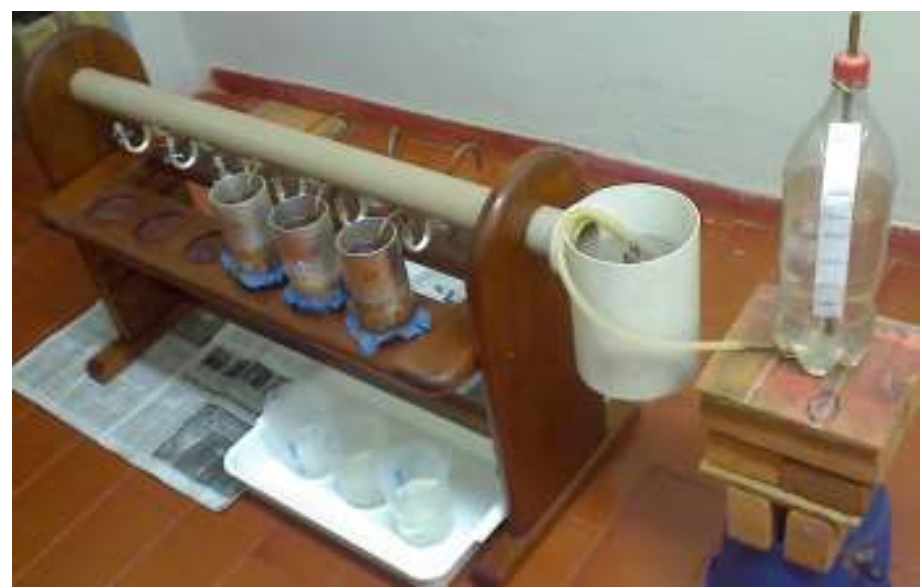

Figure 1. Installation of the constant-head permeameter coupled in a Mariotte bottle at the Laboratory of Soil Pollution where the study was conducted.

After passing through the soil, treated wastewater samples were collected for analysis of EC, SAR, turbidity, $\mathrm{pH}, \mathrm{Na}, \mathrm{K}, \mathrm{Mg}, \mathrm{P}$ and $\mathrm{Ca}$. The granulometry of the soil was measured in the Laboratory of Soil Physics (CCA/UFSCar), saturated hydraulic conductivity (Ksat) was analyzed by the methodology described by Libardi (1999), using concentric rings in the same laboratory and the complete fertility and the exchangeable sodium percentage (ESP) were obtained in the Laboratory of Plant and Soil Chemistry (CCA/UFSCar). All parameters were analyzed according to the methodologies described in the Standard Methods for Examination of Water and Wastewater (APHA et al., 2000). Results were subjected to variance analysis and measurements were compared using the Tukey Test at $5 \%$ of probability.

\section{RESULTS AND DISCUSSION}

\subsection{Quality of the treated wastewater applied to the soil}

To evaluate the quality of the treated wastewater used in this experiment its initial characteristics (Table 1) were compared to two recommendations for vegetable irrigation (Trani et al., 2011) and soil salinity risk (Ayers and Westcot, 1999).

The parameters described in Table 1 are in agreement with the standards of vegetable irrigation as set forth by Train et al. (2011), except for nitrate concentrations $\left(47 \mathrm{mg} \mathrm{L}^{-1}\right)$ which were higher than the recommended maximum of $10 \mathrm{mg} \mathrm{L}^{-1}$.

According to the standards determined by Ayers and Westcot (1999), in order to guarantee the quality of irrigation water and to avoid the salinization of soil, treated wastewater used must conform to recommended values. The wastewater's values of $\mathrm{P}$ (10.84 $\left.\mathrm{mg} \mathrm{L}^{-1}\right), \mathrm{K}\left(26.4 \mathrm{mg} \mathrm{L}^{-1}\right)$ and $\mathrm{Na}\left(53.7 \mathrm{mg} \mathrm{L}^{-1}\right)$ prior to passing through the soil were 
higher than the maximum recommended values of $10.2 \mathrm{mg} \mathrm{L}^{-1}, 2.0 \mathrm{mg} \mathrm{L}^{-1}$ and $40 \mathrm{mg} \mathrm{L}^{-1}$, respectively.

The electrical conductivity $\left(0.8 \mathrm{dS} \mathrm{m}^{-1}\right)$ and sodium adsorption ratio $\left(3.9\left(\mathrm{mmol}_{\mathrm{c}} \mathrm{L}^{-1}\right)^{1 / 2}\right)$ indicated a restriction of soil application from slight to moderate in relation to the toxicity of sodium ions at the irrigation surface and also affected infiltration potential.

\subsection{Physical soil properties after treated wastewater application}

The application of saline/sodic water results in a reduction of crop size and deterioration of the physical/chemical properties of the soil (Singh et al., 2012). In this sense, excess sodium in the soil promotes the disaggregation of soil particles and soil disruption, consequently reducing saturated hydraulic conductivity and making the assimilation of other elements such as calcium, magnesium and potassium difficult (Almeida, 2010; Meurer, 2010; Varallo et al., 2012). In Table 2, Ksat indicates a soil that has moderate hydraulic conductivity (0.04 and $0.05 \mathrm{~cm} \mathrm{~min}^{-1}$ ) according to the classification described by Bernardo et al. (2006) for the control group and for cycles 3 and 5. For the other cycles, the soil presented a moderately slow Ksat. The analysis of variance indicated that there was no significant difference between the treatments and the amount of water used.

Table 2. Comparison of saturated hydraulic conductivity (Ksat) means by Tukey test at 5\% significance of distilled water and reused treated water after passing through the soil.

\begin{tabular}{cccccccc}
\hline Parameters & & cycle 1 & cycle 2 & cycle 3 & cycle 4 & cycle 5 & Mean \\
\hline \multirow{3}{*}{ Ksat $\left(\mathrm{cm} \mathrm{min}^{-1}\right)$} & T.W. & $0.02 \mathrm{aA}$ & $0.10 \mathrm{aA}$ & $0.10 \mathrm{aA}$ & $0.02 \mathrm{aA}$ & $0.04 \mathrm{aA}$ & $0.06 \mathrm{a}$ \\
& D.W. & $0.05 \mathrm{aA}$ & $0.05 \mathrm{aA}$ & $0.04 \mathrm{aA}$ & $0.04 \mathrm{aA}$ & $0.04 \mathrm{aA}$ & $0.05 \mathrm{a}$ \\
& Mean & $0.04 \mathrm{~A}$ & $0.07 \mathrm{~A}$ & $0.07 \mathrm{~A}$ & $0.03 \mathrm{~A}$ & $0.04 \mathrm{~A}$ & 0.05 \\
\hline
\end{tabular}

T.W. - Treated Wastewater; D.W. - Distilled Water - (Means followed by the same letter do not differ by Tukey Test at 5\%, lower case letter (a) represents the column and capital letter (A) the line).

The amount of clay in the soil did not vary between the treatments during the experiment, showing the same values on cycles 2,3 , and 5 . The quantity of silt increased by $30 \%$ when comparing cycles 1 and 4; this increase occurred when the total sand values were also increased, mainly in cycle 4 (Table 3 ). Taking into account the spatial variability of the soil, it is possible to affirm that there were no differences in soil particle size between the treatments and simulated cycles that can be attributed to the application of treated wastewater.

Table 3. Granulometric analysis of the soil after the passing of treated wastewater and distilled water.

\begin{tabular}{lccccc}
\hline \multirow{2}{*}{ Treatments } & Clay & Coarse & Fine Sand & Total Sand & Silt \\
\cline { 2 - 6 } & \multicolumn{5}{c}{$(\%)$} \\
\hline Distilled water & 70 & 7 & 9 & 16 & 14 \\
cycle 1 & 73 & 8 & 9 & 17 & 10 \\
cycle 2 & 66 & 9 & 8 & 17 & 17 \\
cycle 3 & 66 & 9 & 9 & 18 & 16 \\
cycle 4 & 61 & 9 & 10 & 19 & 20 \\
cycle 5 & 66 & 8 & 9 & 17 & 17 \\
\hline
\end{tabular}

3.3. Chemical properties of the treated wastewater and of the soil at the end of the cycles

The decline of the SAR during cycle 2 (Table 4) can be justified by the decrease of Na. According to the Tukey Test at a significance of 5\%, after passing through the soil the SAR 
values did not present a significant difference when different amounts of water were applied.

After passing through the soil, the treated wastewater showed turbidity values between 1.72 and 4.42 UNT, which represent a tendency of disaggregation of soil particles and soil leaching by the water (Table 4).

Table 4. Comparison of means of water's chemical properties by Tukey test at 5\% significance considering the distilled water and reused treated water after filtration through soil.

\begin{tabular}{|c|c|c|c|c|c|c|c|}
\hline Parameters & & cycle 1 & cycle 2 & cycle 3 & cycle 4 & cycle 5 & Mean \\
\hline \multirow{3}{*}{$\underset{\left(\operatorname{mmol}_{\mathrm{c}} \mathrm{L}^{-1}\right)^{1 / 2}}{\mathrm{SAR}}$} & T.W. & $3.49 \mathrm{aA}$ & $2.37 \mathrm{aA}$ & $3.45 \mathrm{aA}$ & $3.96 \mathrm{aA}$ & $4.30 \mathrm{aA}$ & $3.45 \mathrm{a}$ \\
\hline & D.W. & $0.10 \mathrm{bA}$ & $0.13 \mathrm{bA}$ & $0.07 \mathrm{bA}$ & $0.05 \mathrm{bA}$ & $0.03 \mathrm{bA}$ & $0.08 \mathrm{~b}$ \\
\hline & Mean & $1.45 \mathrm{~A}$ & $1.25 \mathrm{~A}$ & $1.76 \mathrm{~A}$ & $2.00 \mathrm{~A}$ & $1.74 \mathrm{~A}$ & 1.64 \\
\hline \multirow{3}{*}{$\mathrm{pH}$} & T.W. & $7.62 \mathrm{aA}$ & $7.38 \mathrm{aA}$ & $7.50 \mathrm{aA}$ & $7.40 \mathrm{aA}$ & $7.34 \mathrm{aA}$ & $7.44 \mathrm{a}$ \\
\hline & D.W. & $6.25 \mathrm{aA}$ & $6.24 \mathrm{aA}$ & $6.45 \mathrm{aA}$ & $6.68 \mathrm{aA}$ & $6.71 \mathrm{aA}$ & $6.47 \mathrm{a}$ \\
\hline & Mean & $6.8 \mathrm{~A}$ & $6.81 \mathrm{~A}$ & $6.97 \mathrm{~A}$ & $7.04 \mathrm{~A}$ & $6.96 \mathrm{~A}$ & 6.92 \\
\hline \multirow{3}{*}{$\begin{array}{c}\mathrm{Na} \\
\left(\mathrm{mg} \mathrm{L}^{-1}\right)\end{array}$} & T.W. & $51.15 \mathrm{aA}$ & $42.00 \mathrm{aA}$ & $43.87 \mathrm{aA}$ & $47.37 \mathrm{aA}$ & $50.00 \mathrm{aA}$ & $46.31 \mathrm{a}$ \\
\hline & D.W. & $1.27 \mathrm{bA}$ & $1.97 \mathrm{bA}$ & $0.63 \mathrm{bA}$ & $0.33 \mathrm{bA}$ & $0.20 \mathrm{bA}$ & $0.88 \mathrm{~b}$ \\
\hline & Mean & $21.22 \mathrm{~A}$ & $21.98 \mathrm{~A}$ & $22.25 \mathrm{~A}$ & $23.85 \mathrm{~A}$ & $20.12 \mathrm{~A}$ & 21.97 \\
\hline \multirow{3}{*}{$\begin{array}{c}\mathrm{K} \\
\left(\mathrm{mg} \mathrm{L}^{-1}\right)\end{array}$} & T.W. & $15.40 \mathrm{aA}$ & $9.30 \mathrm{aA}$ & $13.60 \mathrm{aA}$ & $9.40 \mathrm{aA}$ & $14.70 \mathrm{aA}$ & $12.08 \mathrm{a}$ \\
\hline & D.W. & $1.50 \mathrm{bA}$ & $0.97 \mathrm{aA}$ & $0.63 \mathrm{bA}$ & $0.47 \mathrm{aA}$ & $0.40 \mathrm{bA}$ & $0.79 \mathrm{~b}$ \\
\hline & Mean & $7.06 \mathrm{~A}$ & $5.13 \mathrm{~A}$ & $7.12 \mathrm{~A}$ & $4.93 \mathrm{~A}$ & $6.12 \mathrm{~A}$ & 6.04 \\
\hline \multirow{3}{*}{$\underset{\left(\mathrm{mg} \mathrm{L}^{-1}\right)}{\mathrm{Mg}}$} & T.W. & $3.50 \mathrm{aA}$ & $5.00 \mathrm{aA}$ & $3.67 \mathrm{aA}$ & $2.33 \mathrm{aA}$ & $2.50 \mathrm{aA}$ & $3.46 \mathrm{a}$ \\
\hline & D.W. & $5.00 \mathrm{aA}$ & $2.00 \mathrm{aA}$ & $1.00 \mathrm{aA}$ & $1.00 \mathrm{aA}$ & $1.00 \mathrm{aA}$ & $2.00 \mathrm{a}$ \\
\hline & Mean & $4.40 \mathrm{~A}$ & $3.50 \mathrm{~A}$ & $2.33 \mathrm{~A}$ & $1.67 \mathrm{~A}$ & $1.60 \mathrm{~A}$ & 2.68 \\
\hline \multirow{3}{*}{$\begin{array}{c}\mathrm{P} \\
\left(\mathrm{mg} \mathrm{L}^{-1}\right)\end{array}$} & T.W. & $3.28 \mathrm{aA}$ & $2.26 \mathrm{aA}$ & $0.53 \mathrm{aA}$ & $0.64 \mathrm{aA}$ & $2.01 \mathrm{aA}$ & $1.60 \mathrm{a}$ \\
\hline & D.W. & $0.12 \mathrm{bA}$ & $0.22 \mathrm{aA}$ & $0.15 \mathrm{aA}$ & $0.11 \mathrm{aA}$ & $0.11 \mathrm{aA}$ & $0.14 \mathrm{~b}$ \\
\hline & Mean & $1.39 \mathrm{~A}$ & $1,24 \mathrm{~A}$ & $0.34 \mathrm{~A}$ & $0.38 \mathrm{~A}$ & $0.87 \mathrm{~A}$ & 0.82 \\
\hline \multirow{3}{*}{$\begin{array}{c}\mathrm{Ca} \\
\left(\mathrm{mg} \mathrm{L}^{-1}\right)\end{array}$} & T.W. & $20.00 \mathrm{aA}$ & $29.00 \mathrm{aA}$ & $15.67 \mathrm{aA}$ & $11.33 \mathrm{aA}$ & $10.50 \mathrm{aA}$ & $17.62 \mathrm{a}$ \\
\hline & D.W. & $26.67 \mathrm{aA}$ & $10.33 \mathrm{aA}$ & $4.67 \mathrm{aA}$ & $3.00 \mathrm{aA}$ & $2.00 \mathrm{aA}$ & $9.33 \mathrm{a}$ \\
\hline & Mean & $24.00 \mathrm{~A}$ & $19.67 \mathrm{~A}$ & $10.17 \mathrm{~A}$ & $7.17 \mathrm{~A}$ & $5.40 \mathrm{~A}$ & 13.18 \\
\hline \multirow{3}{*}{$\begin{array}{c}\mathrm{NO}_{3}^{-} \\
\left(\mathrm{mg} \mathrm{L}^{-1}\right)\end{array}$} & T.W. & $14.50 \mathrm{aA}$ & $16.43 \mathrm{aA}$ & $15.00 \mathrm{aA}$ & $34.13 \mathrm{aA}$ & $25.00 \mathrm{aA}$ & $21.21 \mathrm{a}$ \\
\hline & D.W. & $4.80 \mathrm{aA}$ & $3.80 \mathrm{aA}$ & $0.27 \mathrm{aA}$ & $0.27 \mathrm{bA}$ & $0.20 \mathrm{bA}$ & $1.87 \mathrm{~b}$ \\
\hline & Mean & $8.68 \mathrm{~A}$ & $10.12 \mathrm{~A}$ & $7.63 \mathrm{~A}$ & $17.20 \mathrm{~A}$ & $10.12 \mathrm{~A}$ & 10.85 \\
\hline \multirow{3}{*}{$\begin{array}{c}\mathrm{EC} \\
\left(\mathrm{dS} \mathrm{m}^{-1}\right)\end{array}$} & T.W. & $0.74 \mathrm{aA}$ & $0.77 \mathrm{aA}$ & $0.60 \mathrm{aA}$ & $0.74 \mathrm{aA}$ & $0.77 \mathrm{aA}$ & $0.72 \mathrm{a}$ \\
\hline & D.W. & $0.31 \mathrm{aA}$ & $0.14 \mathrm{bA}$ & $0.08 \mathrm{bA}$ & $0.06 \mathrm{bA}$ & $0.05 \mathrm{bA}$ & $0.13 \mathrm{~b}$ \\
\hline & Mean & $0.48 \mathrm{~A}$ & $0.45 \mathrm{~A}$ & $0.34 \mathrm{~A}$ & $0.40 \mathrm{~A}$ & $0.34 \mathrm{~A}$ & 0.40 \\
\hline \multirow{3}{*}{$\begin{array}{l}\text { Turbidity } \\
\text { (UNT) }\end{array}$} & T.W. & $1.72 \mathrm{aA}$ & $3.75 \mathrm{aA}$ & $2.39 \mathrm{aA}$ & $2.62 \mathrm{aA}$ & $4.42 \mathrm{aA}$ & $2.96 \mathrm{a}$ \\
\hline & D.W. & $1.64 \mathrm{aA}$ & $2.25 \mathrm{aA}$ & $3.38 \mathrm{aA}$ & $1.58 \mathrm{aA}$ & $1.67 \mathrm{aA}$ & $2.11 \mathrm{a}$ \\
\hline & Mean & $1.67 \mathrm{~A}$ & $3.00 \mathrm{~A}$ & $2.89 \mathrm{~A}$ & $2.10 \mathrm{~A}$ & $2.77 \mathrm{~A}$ & 2.50 \\
\hline
\end{tabular}

T.W. - Treated Wastewater; D.W. - Distilled Water - (Means followed by the same letter do not differ by Tukey Test at 5\%, lower case letter (a) represents the column and capital letter (A) the line).

Soil affected by salt is usually alkaline, which can damage crop development. It is therefore important to determine the $\mathrm{pH}$ in order to characterize the alkalinity of the soil correctly.

The treated wastewater used in this experiment did not cause alterations of the soil's $\mathrm{pH}$ (Table 5) and there was no significant difference between the treated wastewater and the distilled water in relation to this parameter (Table 4). The $\mathrm{pH}$ values were lower than the ones 
indicated by Trani et al. (2011) and similar values obtained by Sandri et al. (2006) and Varallo et al. (2010) confirmed that the wastewater did not cause changes in this parameter. The present results show that the $\mathrm{pH}$ value did not damage the quality of the soil.

Table 5. Results of soil fertility analysis after the filtration of treated wastewater and distilled water through homogenized soil samples.

\begin{tabular}{lcccccc}
\hline Parameters & Control & cycle 1 & cycle 2 & cycle 3 & cycle 4 & cycle 5 \\
\hline $\mathrm{pH}$ & 5.4 & 4.9 & 5.4 & 5.3 & 5.5 & 5.6 \\
$\mathrm{~K}^{*}$ & 2 & 1.9 & 2.3 & 1.8 & 3.2 & 2.2 \\
$\mathrm{Ca}^{*}$ & 18 & 14 & 16 & 16 & 23 & 18 \\
$\mathrm{Na}^{*}$ & 1 & 1.7 & 2.5 & 2 & 3.1 & 3 \\
$\mathrm{Mg}^{*}$ & 4 & 4 & 4 & 4 & 5 & 4 \\
$\mathrm{Al}^{*}$ & 0.4 & 0.5 & 0.4 & 1 & 0.8 & 1 \\
$\mathrm{SB}^{*}$ & 24 & 20 & 22 & 22 & 31 & 24 \\
$\mathrm{CEC} *$ & 48 & 49 & 44 & 44 & 49 & 46 \\
$\mathrm{H}+\mathrm{Al}^{*}$ & 24 & 29 & 22 & 22 & 18 & 22 \\
$\mathrm{O} . \mathrm{M} .\left(\mathrm{g} \mathrm{dm}^{-3}\right)$ & 21 & 20 & 20 & 20 & 18 & 19 \\
$\mathrm{P} * *$ & 5 & 8 & 11 & 10 & 33 & 19 \\
$\mathrm{~V} \%$ & 50 & 41 & 50 & 50 & 63 & 52 \\
$\mathrm{ESP}(\%)$ & - & 7.69 & 9.92 & 8.06 & 8.83 & 10.64 \\
\hline
\end{tabular}

SB: Sum of bases; CEC: Cation-exchange capacity; O.M.: Organic matter; ESP: exchangeable sodium percentage.

* Values in $\mathrm{mmol}_{\mathrm{c}} \mathrm{L}^{-1} * *$ Values in $\mathrm{mg} \mathrm{L}^{-1}$.

The CEC after the filtration of treated wastewater did not present changes between the cycles, except in cycle 4, in which the concentration of phosphorus increased from $10 \mathrm{mg} \mathrm{L}^{-1}$ in cycle 3 to $33 \mathrm{mg} \mathrm{L}^{-1}$ in cycle 4 , and the sum of bases decreased. There was a linear increase of the negative charges, increasing the effective CEC, and simultaneously decreasing the positive charges (Meurer, 2010). In cycle 4, the effective CEC increased due to the concentration of nutrients added by water reuse.

The ESP increased simultaneously with the $\mathrm{Ca}, \mathrm{K}, \mathrm{Na}$ and $\mathrm{Al}$ cations of the soil, as can be seen in Table 5. The ESP values during the experiment did not indicate a saturation of the soil exchange complex by the sodium ions.

The concentration of $\mathrm{Na}$ in treated wastewater before passing through the soil was $53.70 \mathrm{mg} \mathrm{L}^{-1}$; after this, the first cycle presented $51.15 \mathrm{mg} \mathrm{L}^{-1}$ and the fifth $50.00 \mathrm{mg} \mathrm{L}^{-1}$. This result showed that $\mathrm{Na}$ did not accumulate in the soil during the simulated cycles. According to the variance analysis, there was no significant difference between the cycles.

Clay dispersion can occur in soils with high $\mathrm{Na}$ concentration, and a $\mathrm{Na}$ concentration that is too high results in organic matter dispersion (Meurer, 2010). This did not occur during this study. Organic matter values (Table 5) presented a slight tendency to decrease between the simulated cycles, but more cycles would be necessary to attribute this trend to the use of treated wastewater.

The soil samples irrigated with distilled water presented the same Ca concentration as the fifth cycle, being $18.0 \mathrm{mmol}_{\mathrm{c}} \mathrm{dm}^{3}$. In this context, it is possible to conclude that treated wastewater did not promote an increase in $\mathrm{Ca}$ levels in the soil. The analysis of variance showed no significant difference between the different cycles of lettuce cultivation.

During the experiment, the values of Ca presented by the treated wastewater after passing through the soil ranged from $29.33 \mathrm{mg} \mathrm{L}^{-1}$ in cycle 2 to $10.50 \mathrm{mg} \mathrm{L}^{-1}$ in cycle 5 , while in the soil the concentration of Ca in cycle 2 was $16.00 \mathrm{mmol}_{\mathrm{c}} \mathrm{dm}^{3}$ and in cycle $5,18.00 \mathrm{mmol}_{\mathrm{c}} \mathrm{dm}^{3}$. 
It was possible to observe in cycle 2 that $\mathrm{Ca}$ was not retained in the soil but was in fact lixiviated. In cycle 5, Ca was retained in the soil and less lixiviation occurred.

The concentration of $\mathrm{Mg}$ in the soil after the application of distilled water was $4.0 \mathrm{mmol}_{\mathrm{c}} \mathrm{dm}^{3}$ (Table 5) and the same value was observed in soil samples that were irrigated with treated wastewater. This can be explained by the low concentration of $\mathrm{Mg}$ in the treated wastewater $\left(0.17 \mathrm{mg} \mathrm{L}^{-1}\right)$, which can be considered inexpressive in causing changes in soil characteristics, since the recommended values must range from 50 to $110 \mathrm{mg} \mathrm{L}^{-1}$ (Trani et al., 2011). According to soil characteristics, the water collected after the passage the soil cylinders (Table 2) presented no significant difference for both treatments (distilled and treated wastewater). The potassium values in soil when compared with the initial value of $1.9 \mathrm{mmol}_{\mathrm{c}}$ $\mathrm{dm}^{3}$ did not have an expressive increase and concentration on the fifth cycle was $2.2 \mathrm{mmol}_{\mathrm{c}}$ $\mathrm{dm}^{3}$ (Table 5). Varallo et al. (2010) also found no difference for K using wastewater, from 3.5 $\mathrm{mmol}_{\mathrm{C}} \mathrm{dm}^{3}$ in the natural ground to $3.7 \mathrm{mmol}_{\mathrm{c}} \mathrm{dm}^{3}$ after application.

After passing through the soil, the treated wastewater presented $\mathrm{K}$ concentrations between 9.3 and $14.7 \mathrm{mg} \mathrm{L}^{-1}$ (Table 4), and the initial concentration was $26.4 \mathrm{mg} \mathrm{L}^{-1}$ showing a tendency towards accumulation. It is not possible to attribute changes of such nutrient in the soil to the wastewater.

The treated wastewater presented an initial P concentration of $10.84 \mathrm{mg} \mathrm{L}^{-1}$ (Table 1) and the samples of treated wastewater collected after passing through the soil had lower values in comparison with the initial. When compared to the concentration of P retained in the soil, it is possible to conclude that this nutrient presented an accumulation tendency (Table 5).

After passing through the soil, the treated wastewater collected in cycle 5 presented a nitrate concentration of $25.0 \mathrm{mg} \mathrm{L}^{-1}$; this indicated a retention tendency by the soil. The nitrates and ammonium are available forms of nitrogen in plants. In broadleaf plants, such as lettuce and cabbage, nitrogen is beneficial; however, precautions should be taken when the first signals of toxicity occur in the plants (Sandri et al., 2007). Standard values must be respected in order to protect consumers' health and to avoid the contamination of both underground and surface water.

\section{CONCLUSION}

The use of treated wastewater on soil corresponding to five cycles of lettuce cultivation did not damage the physical properties of the soil. However, the initial characterization of the water indicates a slight to moderate salinity risk.

The volume of water that corresponds to five cycles of lettuce cultivation increased the exchangeable sodium percentage, phosphorus and sodium concentrations in soil.

\section{ACKNOWLEDGMENTS}

To FAPESP (Research Support Foundation of São Paulo) for financial support (2010/20081-7) and a scholarship to the first author (2011/02810-4) and to CNPq (National Counsel of Technological and Scientific Development) for the financial support (303583/2012-6) to this experiment.

\section{REFERENCES}

ALMEIDA, O. A. Qualidade da água de irrigação. Cruz das Almas: EMBRAPA Mandioca e Fruticultura, 2010. 
AMERICAN PUBLIC HEALTH ASSOCIATION - APHA; AMERICAN WATER WORKS ASSOCIATION - AWWA; WATER ENVIRONMENT FEDERATION - WEF. Standard methods for examination of water and wastewater. 20. ed. Washington, DC, 2000.

AYERS, R. S.; WESTCOT, D. W. A qualidade da água na agricultura. 2. ed. Campina Grande: UFPB, 1999. 218 p. (Estudos da FAO: Irrigação e Drenagem, 29, Revisado 1).

BAUMGARTNER, D.; SAMPAIO, S. C.; SILVA, T. R.; TEO, C. R. P. A.; VILAS BOAS, M. A. Reúso de águas residuárias da piscicultura e da suinocultura na irrigação da cultura da alface. Engenharia Agrícola, v. 27, n. 1, p. 152-163, 2007. http://dx.doi.org/10.1590/S0100-69162007000100009

BERNARDO, S.; SOARES, A. A.; MANTOVANI, E. C. Manual de Irrigação. 8. ed. Viçosa: UFV, 2006. 625 p.

BONINI, M. A.; SOUZA, C.F.; SATO, L. M.; BASTOS, R.G. Alterações nos atributos de um Latossolo Vermelho Argiloso irrigado com água de reúso e vinhaça. In: CONGRESSO IBÉRICO DE AGRO-ENGENHARIA, 6., 2011, Évora. Anais... Évora: UÉvora, 2011. 1 CD-ROM

CIRELli, G. L.; CONSOLI, S.; LICCIARDELlO, F.; AIELlO, R.; GIUFFRIDA, F.; LEONARDI, C. Treated municipal wastewater reuse in vegetable production. Agricultural Water Management, v. 104, 2012.

http://dx.doi.org/10.1016/j.agwat.2011.12.011

COSTA, Z. V. B.; GURGEL, M. T.; COSTA, L. R.; ALVES, S. M. C., FERREIRA NETO, M.; BATISTA, R. O. Efeito da aplicação de esgoto doméstico primário na produção de milho no assentamento Milagres (Apodi-RN). Revista Ambiente \& Água, v. 9, n. 4, 2014. http://dx.doi.org/10.4136/ambi-agua.1417

CUBA, R. S.; CARMO, J. R.; SOUZA, C. F.; BASTOS, R. G. Potencial de efluente de esgoto doméstico tratado como fonte de água e nutrientes no cultivo hidropônico de alface. Revista Ambiente \& Água, v. 10, n. 3, 2015. http://dx.doi.org/10.4136/ambiagua. 1575

DANTAS, I. L. A.; FACCIOLI, G. G.; MENDONÇA, L. C.; NUNES, T. P.; VIEGAS, R. A.; SANTANA, L. O. G. Viabilidade do uso de água residuária tratada na irrigação da cultura do rabanete (Raphanus sativus L.). Revista Ambiente \& Água, v. 9, n. 1, 2014. http://dx.doi.org/10.4136/ambi-agua.1220

GABRIELLI, G.; PAIXÃO FILHO, J.; CORAUCCI FILHO, B.; TONETTI, A. Ambiance rose production and nutrient supply in soil irrigated with treated sewage. Revista Brasileira de Engenharia Agrícola e Ambiental, v. 19, n. 8, 2015. http://dx.doi.org/10.1590/1807-1929/agriambi.v19n8p755-759

JAVAREZ JR., A.; RIBEIRO, T. A. P.; PAULA JR., D. R. Eficiência do reuso de águas residuárias na irrigação da cultura do milho. Irriga, Botucatu, v. 15, n. 3, 2010. http://dx.doi.org/10.15809/irriga.2010v15n3p231

LIBARDI, P. L. Dinâmica da água no solo. 2. ed. Piracicaba: O autor, 1999. 497 p.

MANTOVANI, E. C.; BERNARDO, S.; PALARETTI, L. F. Irrigação: princípios e métodos. 3. ed. Viçosa: UFV, 2009. 355p. 
MEURER, E. J. Fundamentos de química do solo. 4. ed. Porto Alegre: Evangraf, 2010. 266 p.

NATHAN, O.; NJERI, K. P.; RANG'ONDI, O. E.; SARIMA, C. J. The potential of Zea mays, Commelina bengelensis, Helianthus annuus and Amaranthus hybridus for phytoremediation of waste water. Revista Ambiente \& Água, Taubaté, v. 7, n. 3, 2012. http://dx.doi.org/10.4136/ambi-agua.684

PEDRERO, F.; ALLENDE, A.; GIL, M. I.; ALARCÓN, J. J. Soil chemical properties, leaf mineral status and crop production in a lemon tree orchard irrigated with two types of wastewater. Agricultural Water Management, v. 109, 2012.

http://dx.doi.org/10.1016/j.agwat.2012.02.006

PEREIRA, B. F. F.; HE, Z. L.; SILVA, M. S.; HERPIN, U.; NOGUEIRA, S. F.; MONTES, C. R. et al. Reclaimed wastewater: Impact on soil-plant system under tropical conditions. Journal of Hazardous Materials, v. 192, 2011.

http://dx.doi.org/10.1016/j.jhazmat.2011.04.095

PLEVICH, J. O.; DELGADO, A. R. S.; SAROFF, C.; TARICO, R. C.; CRESPI, R. J.; BAROTTO, O. M. El cultivo de alfalfa utilizando água de perforación, água residual urbana y precipitaciones. Revista Brasileira de Engenharia Agrícola e Ambiental, v. 16, n. 12, 2012. http://dx.doi.org/10.1590/S1415-43662012001200013

REICHARDT, K.; TIMM, L. C. Solo, planta e atmosfera: conceitos, processos e aplicações. Barueri: Manole, 2004.

SAMPAIO, S. C.; CAOVILlA, F. A.; OPAZO, M. A. U.; NÓBREGA, L. H. P.; SUSZEK, M.; SMANHOTTO, A. Lixiviação de íons em colunas de solo deformado e indeformado. Engenharia Agrícola, v. 30, n. 1, 2010.

http://dx.doi.org/10.1590/S0100-69162010000100016

SANDRI, D.; MATSURA, E. E.; TESTEZLAF R. Teores de nutrientes na alface irrigada com água residuária aplicada por sistemas de irrigação. Engenharia Agrícola, v. 26, n. 1, 2006. http://dx.doi.org/10.1590/S0100-69162006000100006

SANDRI, D.; MATSURA, E. E.; TESTEZLAF, R. Desenvolvimento da alface Elisa em diferentes sistemas de irrigação com água residuária. Revista Brasileira de Engenharia Agrícola e Ambiental, v. 11, n. 1, 2007. http://dx.doi.org/10.1590/S141543662007000100003

SINGH, P. K.; DESHBHRATAR, P. B.; RAMTEKE, D. S. Effects of sewage wastewater irrigation on soil properties, crop yield and environment. Agricultural Water Management, v. 103, 2012. http://dx.doi.org/10.1016/j.agwat.2011.10.022

SOUZA, C. F.; BASTOS, R. G.; GOMES, M. P. M.; PULSCHEN, A. A. Eficiência de estação de tratamento de esgoto doméstico visando reuso agrícola. Revista Ambiente \& Água, v. 10, n. 3, 2015. http://dx.doi.org/10.4136/ambi-agua.1549

TRANI, P. E.; TIVELLI, S. W.; CARRIJO, O. A. Fertirrigação em hortaliças. Campinas: IAC, 2011. 51p. (Boletim Técnico, n. 196).

VARAllO, A. C. T.; CARVALHO, L.; SANTORO, B. L.; SOUZA, C. F. Alterações nos atributos de um Latossolo Vermelho-amarelo irrigado com Água de reuso. Revista Brasileira de Engenharia Agrícola e Ambiental, v. 14, n. 4, 2010. http://dx.doi.org/10.1590/S1415-43662010000400005 
VARALLO, A. C. T.; SOUZA, C. F; SANTORO, B. L. Mudanças nas características físicoquímicas de um latossolo vermelho-amarelo distrófico após a irrigação com água de reuso na cultura da alface-crespa (Lactuca sativa, L.). Engenharia Agrícola, v. 32, n. 2, 2012. http://dx.doi.org/10.1590/S0100-69162012000200007 